with pseudohypoparathyroidism (Rodriguez et al., 1974).

\section{Acknowledgments}

We are grateful to Professor J. A. Strong for his advice and for permission to report this patient under his care. We thank Dr M. A. Preece and Dr J. L. H. O'Riordan for the assays of PTH, cyclic-AMP and 25-OHD. J. A. K. is in receipt of a MRC Clinical Research Fellowship and R. J. W. of the Mary Goodger Research Scholarship.

\section{References}

Addison, G.M., Hales, C.N., Woodhead, J.S. \& O'Riordan, J.L.H. (1971) Immunoradiometric assay of parathyroid hormone. Journal of Endocrinology, 49, 521.

Allen, E.H., Millard, F.J.C. \& Nassim, J.R. (1968) Hypohyperparathyroidism. Archives of Disease in Childhood, 43, 295.

Bijvoet, O.L.M. \& Morgan, D.B. (1971) The tubular reabsorption of phosphate in man. In: Phosphate et Métabolisme Phosphocalcique (Ed. by D. J. Hioco), p. 153. Sandoz, Paris.

Chase, L.R. \& Aurbach, G.D. (1967) Parathyroid function and the renal excretion of 3 '5'-adenylic acid. Proceedings of the National Academy of Sciences (United States of America), 58, 518.

Clark, L.C. \& BeCK, E. (1950) Plasma alkaline phosphatase activity. Journal of Pediatrics, 36, 335.

Costello, J.M. \& DENT, C.E. (1963) Hypo-hyperparathyroidism. Archives of Disease in Childhood, 38, 397.

GreenberG, B.G., Winters, R.W. \& GrahaM, J.B. (1960) The normal range of serum inorganic phosphorus and its utility as a discriminant in the diagnosis of congenital hypophosphatemia. Journal of Clinical Endocrinology and Metabolism, 20, 364.

Holick, M.F. \& DeLuca, H.F. (1974) Vitamin D metabolism. Annual Review of Medicine, 25, 349.

Preece, M.A., O'Riordan, J.L.H., Lawson, D.E.M \& KODICEK, E. (1974) A competitive protein-binding assay for 25-hydroxycholecalciferol and 25-hydroxyergocalciferol in serum. Clinica chimica acta, 54, 235.

Rodriguez, H.J., Villarkeal, H., Klahr, S. \& SlatoPOLSKY, E. (1974) Pseudohypoparathyroidism type II; restoration of normal renal responsiveness to parathyroid hormone by calcium administration. Journal of Clinical Endocrinology and Metabolism, 39, 693.

RouND, J.M. (1973) Plasma calcium, magnesium, phosphorus and alkaline phosphatase levels in normal British school children. British Medical Journal, 3, 137.

WRONG, O. \& DAVIES, H.E.F. (1959) The excretion of acid in renal disease. Quarterly Journal of Medicine, 28, 259.

\title{
Diffuse vasculitis, eosinophilia, and elevated antibody titre to measles virus
}

\author{
R. C. BUCKNALL* \\ M.B., B.S., M.R.C.P.
}

R. DosHI $\dagger$

M.B., B.S., M.R.C.Path., D.Path.

The Departments of General Medicine and Neuropathology, Frenchay Hospital, Bristol

\section{Summary}

In the original description of serum sickness by Von Pirquet and Schick (1905) vasculitis was described as a feature. This was subsequently shown to be due to circulating immune complexes, which are known to be eosinotactic. The following report describes a case of serum sickness, occurring in a 14-year-old boy, characterized by diffuse vasculitis with communicating hydrocephalus and accompanied by a pronounced eosinophilia. A significantly raised antibody (IgG) titre to measles virus was demonstrated in his serum and

\footnotetext{
* Present appointment: Medical Registrar, Royal National Hospital for Rheumatic Diseases, Bath.

$\dagger$ Present appointment: Consultant Neuropathologist, The Maudsley and The Brook General Hospitals, London.

Correspondence: Dr R. C. Bucknall, Royal National Hospital for Rheumatic Diseases, Upper Borough Walls, Bath, Somerset.
}

indicated that this agent probably provided the initial antigenic stimulus.

\section{Case report}

A 14-year-old white boy of English parentage was admitted as an emergency to the Royal United Hospital, Bath, with a 24-hr history of abdominal pain. This was originally central in position but subsequently radiated to the right iliac fossa. He had also had pain in both sides of the neck. One month before the onset of these symptoms he had had a sore throat and non-productive cough, but no rash. From that time he had remained anorexic and lethargic. There was no previous history of illness except for mild eczema at the age of 2.5 years; this did not persist and there were no other atopic features. $\mathrm{He}$ had had a dry scaly skin since birth and one of his four sisters was similarly affected. He had neither had 


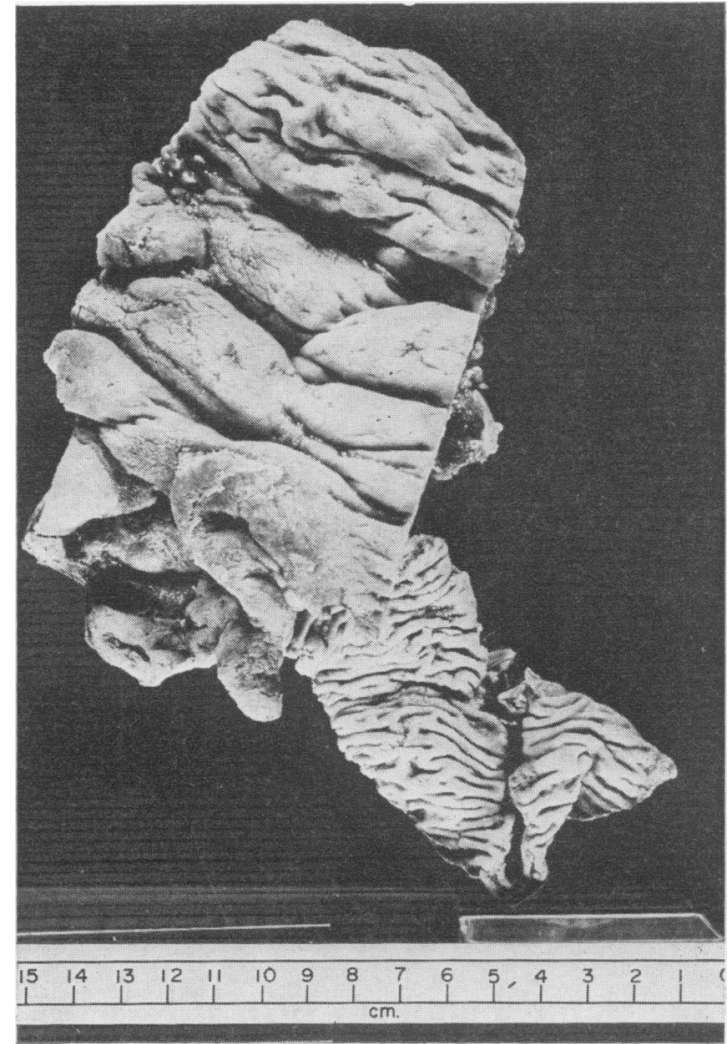

FIG. 1. Resected specimen showing oedematous mucosal folds of ascending colon.

measles nor been immunized against it. At 10 years he was innoculated with the triple vaccine (polio, diphtheria and tetanus) and at 12 years was vaccinated and given BCG; neither was associated with any severe reaction. Apart from a visit of one month to Canada 2 years before his illness, the patient had not been abroad.

On examination, the following physical signs were demonstrated: pyrexia $\left(38^{\circ} \mathrm{C}\right)$, pulse $100 / \mathrm{min}$, b.p. $120 / 80 \mathrm{mmHg}$, lymphadenopathy involving cervical, submandibular and left inguinal groups of nodes; splenomegaly ( $2 \mathrm{~cm}$ below costal margin); tenderness in the lower abdomen, with guarding but no palpable mass. The peripheral blood picture showed: $\mathrm{Hb}$ $14.4 \mathrm{~g} \%$; WBC $31,000 / \mathrm{mm}^{3}$ neutrophils, 23,560 $(76 \%)$; eosinophils, $5890(19 \%)$; lymphocytes, 930 $(3 \%)$; monocytes, $620(2 \%)$; Paul Bunnell test, negative.

A laparotomy was performed and showed the presence of free fluid in the peritoneal cavity, a large mass comprising caecum with marked oedema of surrounding tissue and large fleshy glands in the right mesocolon, with smaller nodes in the mesentery of

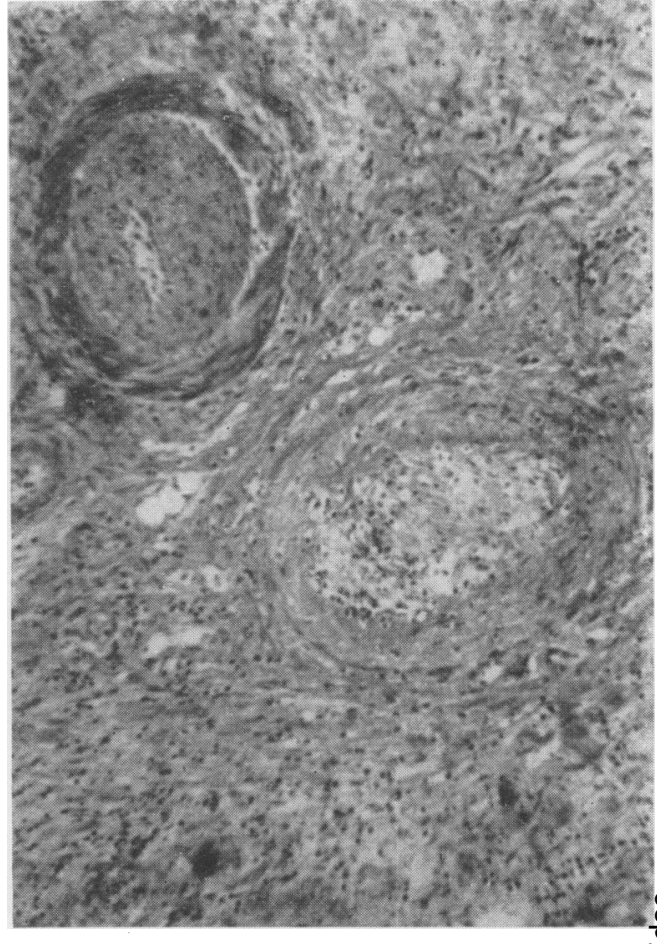

FIg. 2. Caecum $(\times 24)$ showing endarteritis affecting small artery with fibrin thrombi in artery and vein.

the terminal ileum. The presence of a large soft spleen⿳亠丷厂 was confirmed. A right hemicolectomy was performed. Macroscopic examination of the resected $\overrightarrow{0}$ specimen showed that the caecum was ulcerated, with 3 a thin, haemorrhagic wall: the adjacent colon showed huge oedematous mucosal folds (Fig. 1)? Histological examination showed no evidence of으 reticulosis. The submucosa was oedematous with $=$. diffuse infiltration by plasma cells and eosinophils. $\frac{\sigma}{3}$ There was an endarteritis affecting small arteries, fibrin thrombi in capillaries and thrombotic occlu-O sion of venules. Some lymph nodes showed vasculitis in small capillaries (Fig. 2).

Post-operatively his abdominal pain settled, but his pyrexia continued to swing. Further investigation showed WBC, $45,000 / \mathrm{mm}^{3}, 59 \%$ of which were ${ }^{N}$ eosinophils; ESR $90 \mathrm{~mm}$ in first hour; serum albumin $3.0 \mathrm{~g} \%$; globulin $4.6 \mathrm{~g} \%$, with a markedly raised $\gamma$-globulin fraction; serum calcium, $8.9 \mathrm{mg} \% ; \omega$ inorganic phosphate, $5.0 \mathrm{mg} \%$; chest $X$-ray and i.v.p. normal. Two weeks after the operation his condition remained unchanged and he developed $\Phi$ left-sided headaches. Treatment with prednisone $15 \mathrm{mg}$ t.d.s. was commenced, the dose subsequently $\frac{0}{0}$ being increased to $20 \mathrm{mg}$ t.d.s. However, his head- $-\frac{\mathrm{Q}}{\mathrm{D}}$ ache became more severe and he was found to $\frac{\stackrel{P}{\mathbb{P}}}{\sigma}$ 


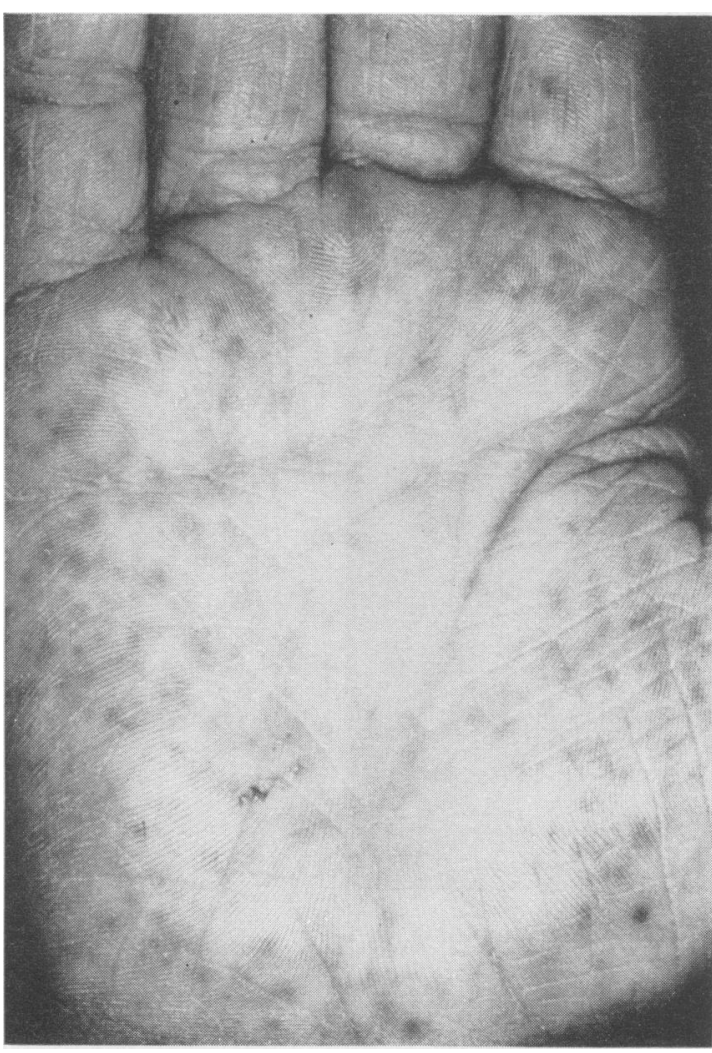

FIG. 3. Hands showing rash due to vasculitis.

have signs of early papilloedema in both fundi. A skull X-ray was normal but an EEG showed rightsided delta wave activity. In view of the possibility of an expanding intracranial lesion the patient was transferred to the neurosurgical unit at Frenchay Hospital, Bristol.

On arrival at Frenchay Hospital he was conscious but drowsy and pyrexial $\left(38 \cdot 5^{\circ} \mathrm{C}\right)$. There was bilateral papilloedema but normal visual activity, a dilated right pupil but reacting briskly to light, bilateral brisk reflexes but motor function and sensation were otherwise normal. A right carotid arteriogram showed elevation of the right middle cerebral artery and intracranial examination via a burr hole showed enlargement of the right temporal horn with c.s.f. under pressure, protein $50 \mathrm{mg} \%$ and $\mathrm{WBC} 7 / \mathrm{mm}^{3}$. Ventriculography showed moderate hydrocephalus with free flow into the cisterna magna and the lumbar c.s.f. pressure was $340 \mathrm{mmHg}$. A Pudenz ventriculoatrial catheter was inserted but in spite of this procedure his condition deteriorated. He complained of severe pain in the muscles of his limbs and back and on examination was found to have a purpuric rash on the palms of both hands (Fig. 3). He still had cervical
TABLE 1

\begin{tabular}{|c|c|}
\hline & Ivestigations \\
\hline \multicolumn{2}{|l|}{ Haematology } \\
\hline \multicolumn{2}{|l|}{ Peripheral Blood } \\
\hline $\begin{array}{l}\text { Hb. } 12 \cdot 0 \mathrm{~g} \% \\
\text { WBC } 94,000 / \mathrm{mm}^{3} \text {. }\end{array}$ & $\begin{array}{l}\text { N } 30,000 / \mathrm{mm}^{3} \\
\text { L } 4700 / \mathrm{mm}^{3} \\
\text { E } 47,000 / \mathrm{mm}^{3} \\
\text { Eosinophil myelocytes } 2820 / \mathrm{mm}^{3} \\
\text { Myelocyte } 1880 / \mathrm{mm}^{3} \\
\text { Staff cells } 8460 / \mathrm{mm}^{3}\end{array}$ \\
\hline Plasma viscosity 1. & $7(1 \cdot 5-1 \cdot 72) \mathrm{cp}$. \\
\hline Bone Marrow & \\
\hline
\end{tabular}

A greater number of neutrophils and myelocytes than in peripheral blood but only $3 \%$ eosinophil myelocytes.

Neutrophil alkaline phosphatase activity-normal.

Chromosome studies performed on white cells from blood and marrow-no evidence of Philadelphia chromosome.

LE cells-not demonstrated

Cryoglobulins-nil

\section{Biochemistry}

Serum electrolytes

$\mathrm{Na}^{+}-131 \mathrm{mEq} / \mathrm{l}$

$\mathrm{K}^{+}-3.8 \mathrm{mEq} / 1$

Urea $-40 \mathrm{mg} \%$

Serum bilirubin $0.8 \mathrm{mg} \%$

Alkaline phosphatase 40 iu/l (50-150)

Urine microscopy

No proteinuria, white or red cells, or casts.

Bacteriology, virology and immunology

Culture of blood, urine and faeces-no pathogens

Toxocara fluorescent antibody-negative

Toxoplasma dye-negative

Brucella agglutination-negative

Complement fixation tests:

Cytomegalovirus

Epstein-Barr virus

Coxsackie B antibodies at

Rickettsia burneti dilution $1 / 8$

Psittacosis

ASO titre-198 Todd units $(<200)$

Widal-negative

Cold agglutinins-1/4 $(<1 / 64)$

WR-negative

Measles antibody titre-1/384-indicating recent infection Serum immunoglobulins

IgG $382 \mathrm{iu} / \mathrm{ml} \quad(50-180)$

IgM $540 \mathrm{iu} / \mathrm{ml} \quad(50-200)$

IgA $137 \mathrm{iu} / \mathrm{ml} \quad(70-250)$

IgE $900 \mathrm{ng} / \mathrm{ml}(<1000)$

lymphadenopathy and splenomegaly and tachycardia but no evidence of valvular heart disease or cardiac failure. Investigations excluded a coagulation defect (CKT $39 \mathrm{sec}$; PTI 1.1; platelets $100,000 / \mathrm{mm}^{3}$; fibrinogen, $317 \mathrm{mg} \%$ ) and the skin lesions were therefore attributed to a vasculitis. Other investigations are shown in Table 1.

Treatment with prednisone $20 \mathrm{mg}$ t.d.s. was continued. Cytotoxic therapy was considered but 


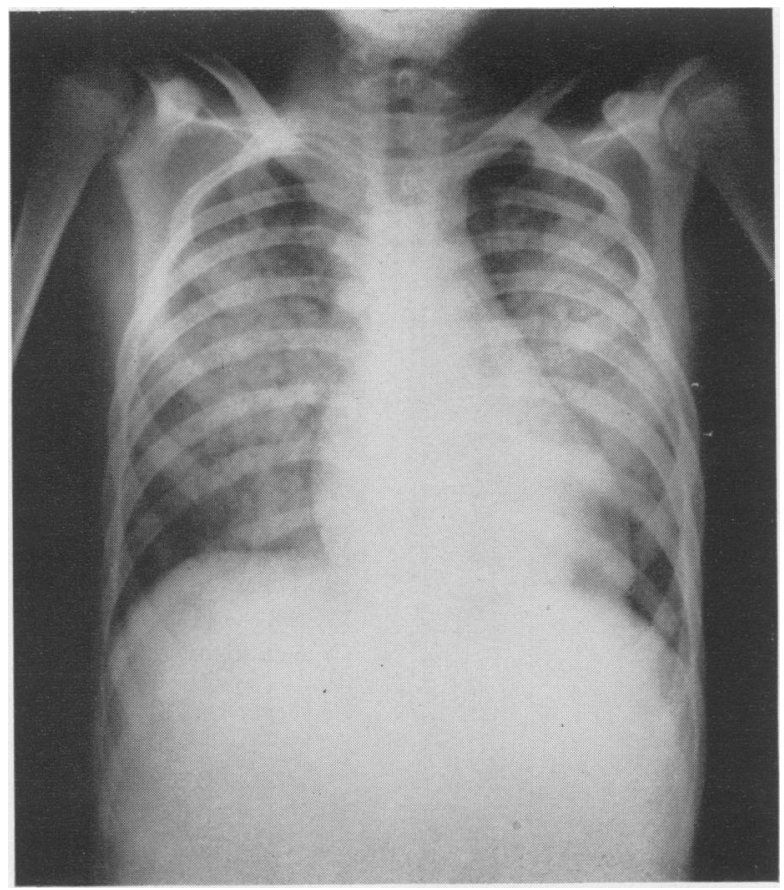

FIG. 4. Chest X-ray showing diffuse miliary mottling.

postponed owing to thrombocytopenia. The patient's condition gradually deteriorated. Although he remained conscious and orientated he developed bilateral pyramidal tract signs. His abdomen became progressively distended and he developed profuse diarrhoea. His respiratory rate increased and although his chest remained clear clinically X-ray showed miliary mottling (Fig. 4). Cyclophosphamide was given in a dose of $100 \mathrm{mg}$ i.v. daily for 4 days but this coincided with a rapid progression in the radiological changes in his lungs, and although the thrombocytopenia became more pronounced there was no reduction in the degree of eosinophilia. Heparin was administered during the last week of his illness. He finally died 3 months after the onset of his illness.

\section{Post-mortem findings}

The brain (1440 g) was somewhat swollen and the coronal slices showed scattered small areas of infarction mainly involving the bases of sulci. Two very small areas of infarction were also present in the cerebellar cortex.

Both lungs ( $R, 345 \mathrm{~g}$; L, $335 \mathrm{~g}$ ) were congested and the cut surface showed haemorrhagic oedema.

The heart $(200 \mathrm{~g})$ was not enlarged but the pericardial sac contained $25 \mathrm{~cm}^{3}$ of clear yellow fluid. There were no vegetations on the valves but tiny yellowish white areas suggestive of necrosis were present in the myocardium. Thrombus was adhereñ to the endocardium.

The large intestine at its proximal end at the site of anastomosis looked somewhat gangrenous but the remaining colon was also congested and dilated. $\stackrel{\mathbb{Q}}{\circ}$ Throughout its entire length there were multiple $\vec{F}$ small, shallow, punched-out areas of mucosal ulcera- 3 tion (Fig. 5). No thrombus was seen in the mesenteric vessels. The liver $(1450 \mathrm{~g})$ was smooth but the cuto surface was fatty; the spleen $(275 \mathrm{~g})$ contained ano infarct $4 \times 4 \times 3 \mathrm{~cm}$; the kidneys $(\mathrm{R}, 85 \mathrm{~g} ; \mathrm{L}, 85 \mathrm{~g}) \stackrel{\text { ? }}{\mathrm{B}}$. showed a congested cortex.

\section{Histological findings}

The areas of infarction in the brain showed proliferation of lymphocytes, plasma cells, fat granule음 cells and astrocytes. At the centre of these infarc- $\rightarrow$ tions there were small blood vessels containing․ fibrin thrombus and their walls were oedematous. N The choroid plexus was infiltrated by inflammatory? cells including eosinophils (Fig. 6).

In addition to multiple areas of infarction in the brain, the heart, spleen, liver, small and large intestine, skin, muscles and nerves showed inflameo matory cell infiltration of the small vessels. Among the inflammatory cells, plasma cells and lymphocytes? predominated but a few eosinophils were also present. $T$ These inflammatory vessels were surrounded by micro infarcts but the large arteries were normal. In 
the kidneys there was necrosis of the proximal tubules but no vasculitis. The main findings in the lungs were alveolar cell metaplasia, interstitial

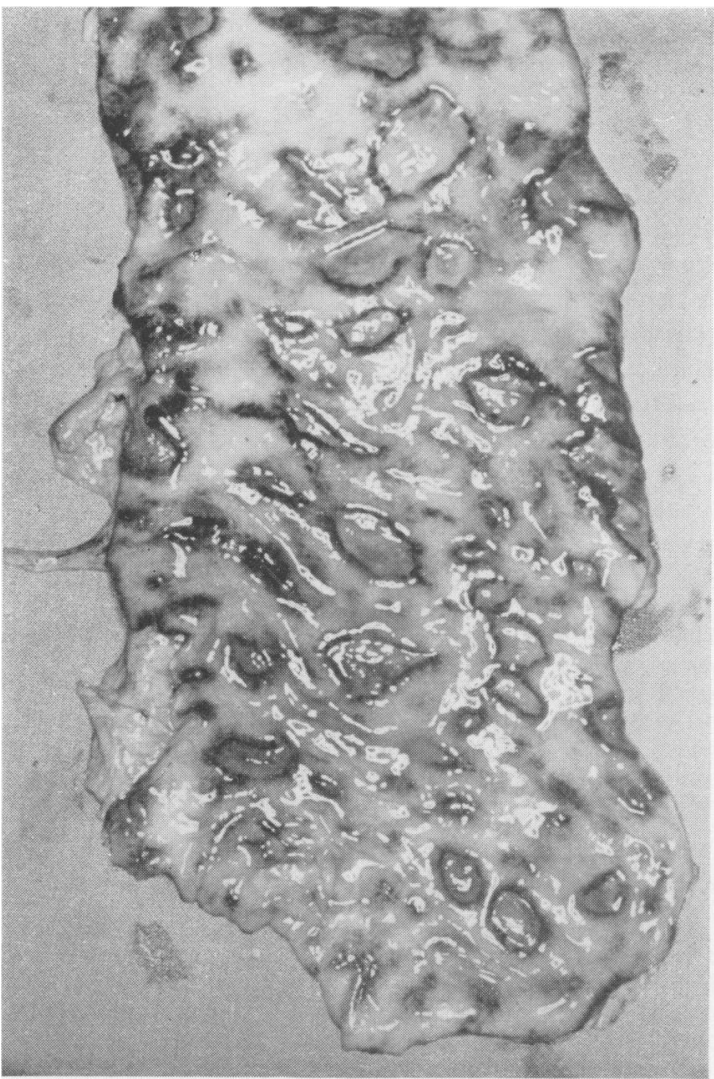

FIG. 5. Post-mortem specimen of colon showing multiple mucosal ulcers. infiltration by lymphocytes, plasma cells and some eosinophils.

\section{Discussion}

Eosinophilia in the peripheral blood may occur as a feature of the following conditions: IgE-mediated (type I) hypersensitivity reactions either in atopic individuals with asthma, hay fever and eczema, or in drug hypersensitivity; pulmonary eosinophilia; parasitic infections, these for the most part occurring in the tropics, but in this country Toxocara canis and T. catis (Woodruff, 1970) and Trichinella spiralis, polyarteritis nodosa; pemphigus and dermatitis herpetiformis, carcinomas and Hodgkin's disease; disseminated eosinophilic collagen disease (Engfeldt and Zetterström, 1956; Pierce, Hosseinian and Constantine, 1967), leukaemia and immune complex diseases.

In the case described, the dominant features are those of pronounced mature eosinophilia in the peripheral blood and marrow, a generalized vasculitis affecting colon, heart, lungs, skin and brain but sparing kidneys, and mural thrombosis with probable systemic embolism. There was no evidence that this represented a type I hypersensitivity reaction to bacterial or parasitic infection; the normal serum IgE concentration supporting this view. On the other hand, the presence of mature eosinophils in the peripheral blood and marrow, the absence of Philadelphia chromosome and normal leucocyte alkaline phosphatase activity, are not consistent with a diagnosis of leukaemia. The clinical features of lymphadenopathy and splenomegaly, absence of renal involvement and the histological features were not compatible with a diagnosis of polyarteritis nodosa. Histological examination of the lymph nodes did not show any evidence of a reticulosis.

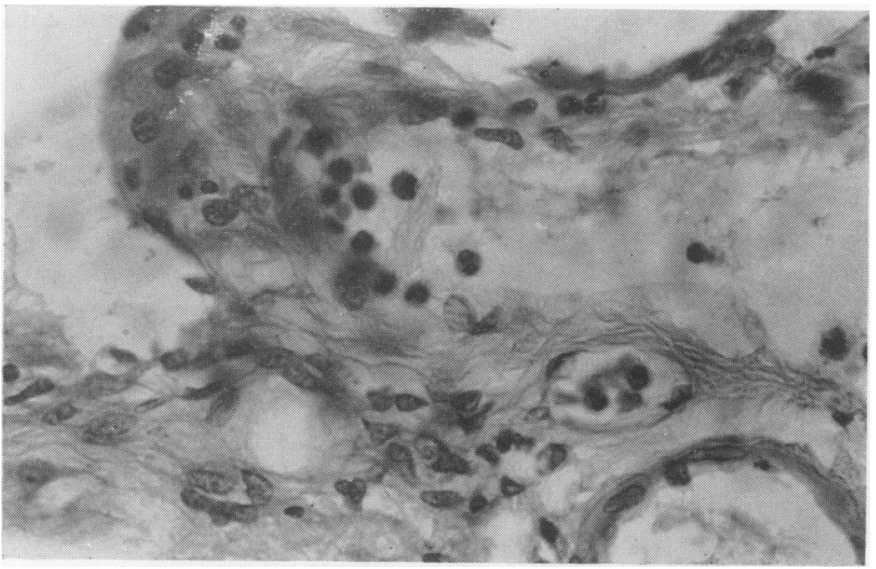

FIG. 6. Choroid plexus infiltrated by inflammatory cells. 
Similar cases are recorded in the literature. The majority have been described as cases of eosinophilic leukaemia. However, various authors have suggested that, in view of the maturity of the eosinophils (Gruenwald et al., 1965), absence of Philadelphia chromosome, normal leucocyte alkaline phosphatase activity and, in many cases, the benign nature of the disease, this is a misnomer (Zuelzer and Apt, 1949; Bentley et al., 1961; Odeburg, 1965).

The title of hypereosinophilic syndrome has been coined (Hardy and Anderson, 1968; Resnick and Myerson, 1971) to describe a wide spectrum of disorders ranging from acute to chronic, benign to malignant, and involving from one to many organs. Hence, at one extreme is the benign disorder of transient pulmonary infiltration associated with eosinophilia (Löffler's syndrome) and at the other, a disseminated vasculitis. A frequent manifestation of the latter is cardiac involvement with mural thrombosis and systemic embolism. In disseminated eosinophilic collagen disease there are, in addition to eosinophilia and vasculitis, dermatological manifestations characteristic of dermatomyositis.

Although neurological involvement has been described in this syndrome, the feature of communicating hydrocephalus has not been alluded to. In life, it was postulated that the mechanism was impaired drainage of c.s.f. into the intracranial venous sinuses as a result of thrombosis. This was not confirmed at post-mortem examination. However, the choroid plexus was infiltrated with inflammatory cells, probably secondary to immune complex deposition as this has been described in systemic lupus erythematosus (Atkins et al., 1971). It is postulated that the raised intracranial pressure was due to excess c.s.f. secretion.

The pronounced eosinophilia in this case is probably related to immune complex formation as these are known to be eosinotactic (Parish, 1972). In addition, as a part of the reparative process following vasculitis, large concentrations of fibrin are deposited and it has been shown experimentally (Riddle and Barnhart, 1965) that eosinophils play a part in the process of fibrinolysis. Profibrinolysin (plasminogen) is localized in the eosinophilic granules and eosinophils have been seen to be attracted to loci where fibrin is being deposited.

Of particular interest in this case is the high serum antibody titre to measles virus. The level detected was consistent with recent infection. The exanthem of measles is an immune complex manifestation, and immune complex nephropathy has been described in this disease. Immune complexes have been described as a feature of sub-acute sclerosing panencephalitis (SSPE) in which condition measles virus has been demonstrated in cerebral tissue (Dayan and Stokes, 1972). However, there is no previous report of measles being associated with disseminated vasculitis气̄ with eosinophilia.

It seems likely that this patient had a $\mathrm{T}$ cell (cell mediated immunity) defect and died of an unsuccess.ful attempt to counter a measles infection. He had not, however, previously indicated any evidence of impaired immunity to viral infections. Studies of T듬 cell function were not carried out but as measles $\overline{\frac{5}{5}}$ infection may itself impair cell-mediated immunity $\overrightarrow{\widetilde{D}}$ (White and Boyd, 1973), results would have been difficult to interpret. However, the presence of measles specific IgG, with no measles specific $\operatorname{IgM}, \vec{\circ}$ in the serum * would suggest that $\mathrm{T}$ cell function was normal. It is important to note that there was now associated elevation of antibodies to other viruseso tested. If this had been the case it would have indi- $\frac{0}{3}$ cated a generalized hyperimmune state (Phillips and Christian, 1973) and would not have favoured? measles as an aetiological agent.

* The technique used to determine the immunoglobulinĩ class of the measles antibody was that of indirect immunofluorescence with measles-infected Vero cells grown at $30^{\circ} \mathrm{C} .0$ These were treated with the IgM fraction of the patient's serum (separated on a sucrose density gradient) and a conju- $\overrightarrow{-}$ gated anti-human IgM serum. The IgM fraction of the patient's serum was tested with a conjugated anti-human IgG serum. It has been shown that this method could detect measles IgM by doing the test with an early convalescosit measles serum containing measles IgM.

\section{Acknowledgments}

We wish to thank Dr D. W. Pugh and Dr J. M. Naish for permission to publish this case and Dr D. B. Brownell ando Dr J. Verrier Jones for helpful advice. Dr R. L. Bishton, who carried out histological examination of the operative specimen, kindly lent us photographs of Figs 1 and 2. Haemato-oㅡㅡ logical investigations were carried out by Dr R. D. Eastham 3 and his staff, and chromosome studies by $\mathrm{Dr}$ Lewis at Southmead Hospital. The Toxocara fluorescent antibody testo was performed by Professor Woodruff and viral studies carried out by Dr S. K. R. Clarke of the Public Health윽 Laboratory, Bristol. We thank especially Mr E. O. Caul of:that laboratory, who classified the measles antibody class.

\section{References}

Atkins, C.J., Kondon, J., Quismorio, F. \& Friou, G. (1971)o The choroid plexus in systemic lupus erythematosus. (Abstract) Annals of the Rheumatic Diseases, 30, 333. Bentley, H.P., REARdon, A.E., KNOEdLeR, J.P. \& KRIVIt, W. (1961) Eosinophilic leukemia. American Journal of Medicine, 30, 310.

DAYAN, A.D. \& Stokes, M.I. (1972) Immune complexes and visceral deposits of measles antigens in subacute sclerosing panencephalitis. British Medical Journal, 2, 374.

ENGFELDT, B. \& ZetTerstrom, R. (1956) Disseminatedo eosinophilic collagen disease. Acta medica scandinavica 153, 337.

Gruenwald, H., Kiossoglou, K.A., Mitus, W.J. \&岇 DAMASHEK, W. (1965) Philadelphia chromosome in? eosinophilic leukemia. American Journal of Medicine, 39, 0 1003.

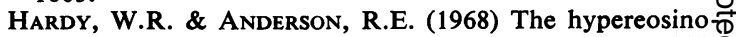
philic syndromes. Annals of Internal Medicine, 68, 1220 
ODEBURG, B. (1965) Eosinophilic leukaemia and disseminated eosinophilic collagen disease-a disease entity? Acta medica scandinavica, 177, 129.

Phillips, P.E. \& Christian, C.L. (1973) Virus antibodies in SLE and other connective tissue diseases. Annals of the Rheumatic Diseases, 32, 480.

Pierce, L.E., Hosseinian, A.H. \& Constantine, A.B. (1967) Disseminated eosinophilic collagen disease. Blood, 29, 540.

PARISH, W.E. (1972) Eosinophilia in guinea-pigs mediated by passive anaphylaxis and by antigen-antibody complexes containing homologous $\operatorname{IgG}_{1}$ a and $\mathrm{IgG}_{1}$ b. Immunology, 22, 1087.

RIDDLE, J.M. \& BARnharT, M.I. (1965) The eosinophil as a source for profibrinolysin in acute inflammation. Blood, 25, 776.

Resnick, M. \& Myerson, R.M. (1971) Hypereosinophilic syndrome. American Journal of Medicine, 51, 560.

Von Pirquet, C. \& Schick, B. (1905) Die Serum Krankheit. Deutiche, Leipzig \& Vienna.

White, R.G. \& BoYD, J.F. (1973) Effects of measles on thymus and other lymphoid tissue. Clinical and Experimental Immunology, 13, 343.

WoODruff, A.W. (1970) Toxocariasis. British Medical Journal, 3, 663.

Zuelzer, W.W. \& APT, L. (1949) Disseminated visceral lesions associated with extreme eosinophilia. American Journal of Diseases of Childhood, 78, 153.

\section{Granulomatous gastritis, iron deficiency, vitamin $B_{12}$ malabsorption and immunoglobulin deficiency}

\author{
I. L. WOOLF \\ B.M., M.R.C.P. \\ R. T. SHAHANI \\ M.B., M.R.C.P.
}

\author{
I. W. DYMOCK \\ M.B., F.R.C.P.E., F.R.C.P.Glasg. \\ B. W. OTRIDGE \\ M.B., M.R.C.P.E., M.R.C.Path.
}

\section{Summary}

A 24-year-old male with recurrent iron deficiency anaemia was found to have a generalized reduction in his immunoglobulin levels, granulomatous gastritis and impaired vitamin $B_{12}$ absorption corrected by Intrinsic Factor.

There is discussion of the possibility that cell mediated mechanisms may have been involved in the cause of the vitamin $B_{12}$ malabsorption.

\section{Introduction}

Granulomatous gastritis is generally considered to be a rare condition and the usual clinical presentation is with signs of pyloric obstruction (Fahimi et al., 1963). With the advent of fibre-optic endoscopy and associated biopsy techniques it is possible that in the future it may be recognized with greater frequency. A patient is described who presented initially with evidence of iron deficiency, who was found to have achlorhydria and vitamin $B_{12}$ malabsorption and in whom the histological appearances were highly unusual, showing atrophic gastritis and accompanying granulomata in all areas of the stomach. Further

Correspondence: Dr B. W. Otridge, Department of Haematology, University Hospital of South Manchester, Manchester M20 8LR. investigations revealed the additional feature of an immunoglobulin deficiency involving all immunoglobulin classes.

\section{Case report}

The patient, a 24-year-old male, presented initially with a complaint of lethargy. Although routine physical examination revealed no abnormality, he was found to be mildly anaemic with a blood film suggesting iron deficiency. Eleven years prevously he had been investigated for a similar hypochromic anaemia associated with diarrhoea, but the investigations had been inconclusive and the symptoms had remitted spontaneously. Shortly after being seen he developed upper abdominal pain and vomiting and was admitted for investigation. The haemoglobin was $12.6 \mathrm{~g} \%$ with hypochromia and microcytosis on the film. The white cell count and platelet count were normal. The bone marrow aspirate showed normoblasts and micronormoblasts with no stainable iron. The serum iron was 35 and TIBC $444 \mu \mathrm{g}^{\%}$. The serum $\mathrm{B}_{12}$ was $285 \mathrm{pg} / \mathrm{ml}$ and serum folate $4.7 \mathrm{ng} / \mathrm{ml}$. Two of six stool samples were positive for occult blood and the faecal fat excretion was $2.7 \mathrm{~g} /$ day. The serum globulin was low at $1.8 \mathrm{~g} \%$ with an IgG of $355 \mathrm{mg} \%$ (normal $800-1600 \mathrm{mg} \%$ ), 